Available online on 15.03.2019 at http://ujpr.org
Universal Journal of Pharmaceutical Research
An International Peer Reviewed Journal
Open access to Pharmaceutical research

\title{
A REVIEW ON MEDICINAL USES OF DIFFERENT PLANTS OF
} EUPHORBIACEAE FAMILY

\author{
Md. Shahidul Islam*1 (iD, Hasnat Ara ${ }^{1}$, Kazi Ishtiaq Ahmad ${ }^{2}$, Md. Mayin Uddin² \\ ${ }^{l}$ Department of Pharmacy, University of science and Technology Chittagong (USTC), Foy's Lake, Chittagong, Bangladesh. \\ ${ }^{2}$ Department of Pharmacy, East West University, Dhaka, Bangladesh.
}

\section{ABSTRACT}

Euphorbiaceae is an important family which contains numerous medicinal plants. Most of the people in developing countries still today, relays on traditional medicine based largely on species of plants in human being and animals for their primary healthcare. The family Euphorbiaceae is one of the largest family of flowering plants comprising of plants with over 300 genera and 8,000 species. Acalyphaindica L, Euphorbia hirta L, Euphorbia thymifolia L, Croton bonplandianumbaill, Jatropha gossypifolia L, Ricinus communis $\mathrm{L}$ are important plants of this family because these plants have different compounds like alkaloids, flavonoids, steroids, saponin, phenolic compounds, fatty acid, esters, minerals etc that have showed different activities in human being and animal. This study provides important data for identification of different plants in Euphorbiaceae family. Species of Euphorbiaceae are extensively used as remedies against several diseases and complaints such as cancer, diabetes, diarrhoea, heart diseases, hemorrhages, hepatitis, jaundice, malaria, ophthalmic diseases, rheumatism and scabies etc.

Keywords: Activity, Euphorbiaceae, medicinal plants, uses.

Article Info: Received 1 January 2019; Revised 9 February; Accepted 3 March, Available online 15 March 2019

$\square$ Cite this article-

Islam MS, Ara H, Ahkad K, Uddin MM. A review on medicinal uses of different plants of Euphorbiaceae family. Universal Journal of Pharmaceutical Research 2019; 4(1): 45-49.

DOI: https://doi.org/10.22270/ujpr.v4i1.236

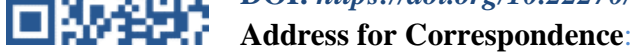

Md. Shahidul Islam, Assistant Professor, Department of Pharmacy, University of Science and Technology Chittagong (USTC), Bangladesh. Tel: +8801815-579040, E-mail: s_i_liton@yahoo.com

\section{INTRODUCTION}

Plants for human healthcare still remain the most widely used medication system in developing and least developed nation. Population rise, insufficient supply of drugs, unaffordable cost of treatments, side effects of several allopathic drugs and development of resistance to currently used drugs for diseases have led to increased emphasis on the use of plant materials as a source of medicines for wide variety of human ailments ${ }^{1}$. Different types of plants used to treat various types of diseases that reveals the most up to date findings in understanding of biological significance of their bioactive compounds used ${ }^{2}$. Recently, dramatic changes have taken place in the health care system of world population through the development of science, technology and medical science but till to day 400 crores of people of the world are totally dependent on herbal medicines. Despite all the progress in synthetic chemistry and biotechnology, plants are still in an indispensible source of medicinal preparations both preventive and curative. WHO consultative body of medicinal plants has formulated a definition of medicinal plants in the following way, "a medicinal plant is any plant which in one or more of its organ, contains substances that can be used for therapeutic purposes or which is a precursor for synthesis of useful drugs". . Medicinal plants, also called medicinal herbs, include a various types of plants used in herbalism and some of these plants have a medicinal activities. These medicinal plants are considered as a rich resources of ingredients which can be used in drug development and synthesis ${ }^{3}$. Besides that these plants play a critical role in the development of human cultures around the whole world ${ }^{4}$. The uses of plants in the indigenous cultures particularly of developing countries, are numerous and diverse, forming an important socioeconomic base ${ }^{5}$. Phytochemistry is the study of photochemical produced in plants, describing the isolation, purification, identification, and structure of the large number of secondary metabolic compounds found in plants ${ }^{6}$. The Euphorbiaceae, the spurge family, is a large family of flowering plants. In common English, they are sometimes called euphorbias, which is also the name of a genus in the family. The Euphorbiaceae are mostly monoecious herbs, shrubs, and trees, sometimes succulent and cactus-like, 
comprising one of the largest families of plants with about 300 genera and 7,500 species ${ }^{7}$.

The main aim of this review study was to investigate the secret behind the medicinal uses of the plants of Euphorbiaceae family, to find out other medicinal uses which could be present in the plant to establish a scientific data on its medicinal value. Therefore, taking into consideration the traditional uses of the plant and facilities available for conducting the study, this research work was performed on the Euphorbiaceae plants family. The principle aim of the present study was to investigate the scientific basis of the traditional uses of the plants. Euphorbiaceae family of plants was studied for other medicinal uses possible and to find out the chemical groups present in the active plant parts to get priliminary idea about the active constituents. The Euphorbiaceae has 65 genera and 577 species accepted taxa overall. But Acalypha indica L, Euphorbia hirta L, Euphorbia thymifolia L, Croton bonplandianum baill, Jatropha gossypifolia L, Ricinus communis L are important of this family because these plants shown different activity for different diseases. Plants have remarkable medicinal and traditional uses.

\section{ACALYPHA INDICA L.}

The total description and the medicinal uses of the plants of theApocynaceae family are given below:

- Botanical Name: A. indica .

- Binomial Name: Acalyphaindica L

- Local Name: Muktajhuri.

- Family: Euphorbiaceae.

Habit: Small herb, rarely sub-shrub.

Habitat: Waste, moist and shady places and river banks

Flower color: Olive green.

Flowering season: December-April.

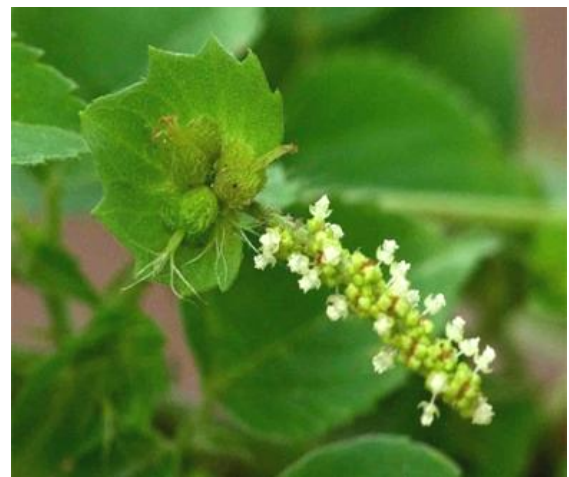

Figure 1: Acalypha indica L.

\section{Parts utilized}

Leaves, stem, flowers, rootsand seeds

Medicinal uses

- Plants are emetic, expectorant, laxative and diuretic; useful in bronchitis, pneumonia, asthma and pulmonary tuberculosis. Leaves are laxative and antiparasitic; ground with common salt or quicklime or lime juice applied externally in scabies $^{8}$.

- Leaf paste with lime juice prescribed for ringworm. Leaf juice is emetic for children.
- Powder of the dry leaves is given to children to expel worms; also given in the form of decoction with little garlic.

- In homeopathy, the plant is used in severe cough associated with bleeding from lungs, haemoptysis and incipient phthisis.

- The plant is expectorant, diuretic, emetic and laxative. Fresh leaf juice is useful in arthritis and scabies. Dry leaf powder is used in bed sores.

\section{EUPHORBIA HIRTA L.}

- Botanical Name: $E$. hirta $L$.

- Binomial Name: Euphorbiahirta L.

- Local Name: Dudhia.

- Family: Euphorbiaceae.

Habit: Shrub.

Habitat: Gardens where it is cultivated as an ornamental plant.

Flower colour: Red.

Flowering season: December-February.

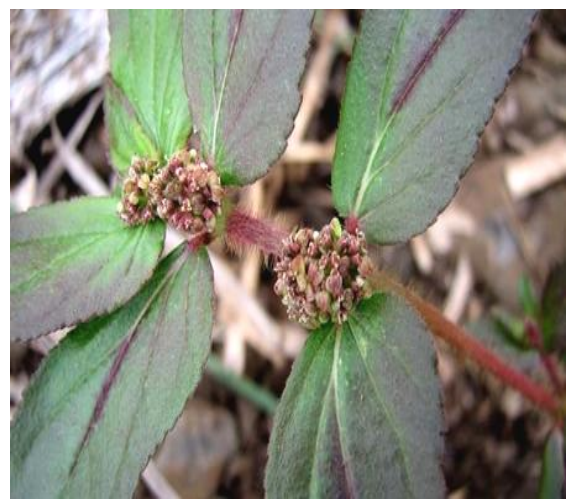

Figure 2: Euphorbia hirta $L$.

\section{Parts utilized}

Leaves, stem and rootsand flower

Medicinal uses

- The plant is astringent and haemostatic; as poultice applied to abscesses, inflamed glands, ulcers, oedema and phlegmon and also used in affections of childhood, in worms, bowel complaints and cough ${ }^{9}$.

- The juice is considered tonic, narcotic, antiasthmatic and febrifuge; effective against dysentery, diarrhoea and colic; especially in amoebiasis. Decoction is useful in asthma and chronic bronchial affections.

- The extract of this plant has sedative effect on the mucous membrane of the respiratory and genitourinary tract and on cardiovascular system.

- The plant has as an analgesic to treat severe headache, toothache, rheumatism, colic, and pains during pregnancy.

\section{EUPHORBIA THYMIFOLIA L.}

- Binomial Name : Euphorbia thymifolia L.

- Local Name: Dudhiya.

- Family: Euphorbiaceae.

Habit: Herb.

Habitat: Open sunny places.

Flower color: Reddish-purple.

Flowering season: April-August. 


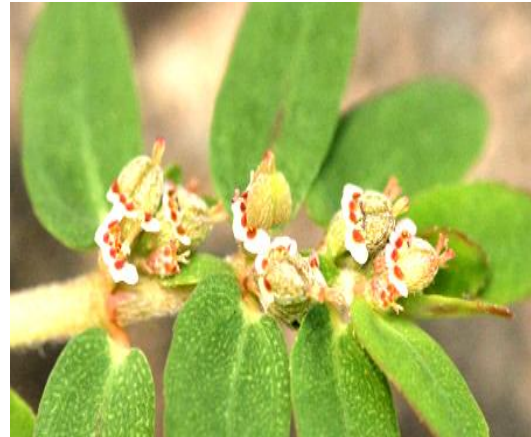

Figure 3: Euphorbia thymifolia L.

\section{Parts utilized}

Leaves, roots, flowers and whole plant.

\section{Medicinal Uses}

- The fresh plant is used in ophthalmia and other eye troubles, ardor, sores, atrophy, dysentery and breast pain.

- It is an effective drug for bronchial asthma.

- Juice of the plant is used for ringworm, diarrhea and dysentery; mixed with fresh goat milk is given to cure blood dysentery.

- Leaves and seeds are astringent, stimulant, anthelmintic and laxative; given to children in bowel complaints. Root is used in amenorrhea.

- Euphorbia thymifolia $L$ is widely used in decoction or infusion against dysentery, enteritis, diarrhoea and venereal diseases. The dried leaves areused as a stimulant, astringent, antihelmintic and laxative.

\section{CROTON BONPLANDIANUMBAILL}

- Botanical Name : C. bonplandianumbaill.

- Binomial Name :Croton bonplandianumbaill.

- Local Name : Bondhone.

- Family: Euphorbiaceae.

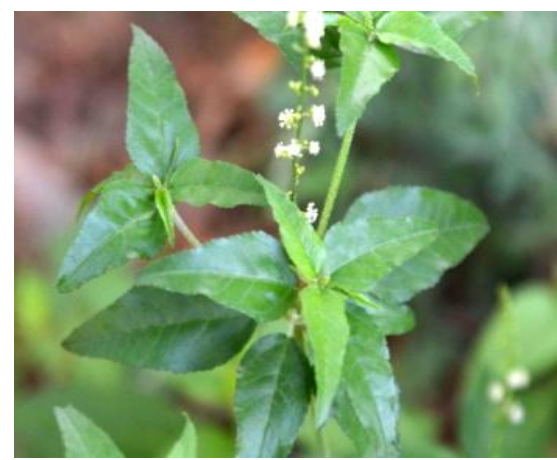

Figure 4: Croton bonplandianumbaill

Habit: herb.

Habitat: Dry and sandy exposed areas.

Flower color: White.

Flowering season: April-September

Parts utilized:

Leaves, fruits and flowers.

\section{Medicinal uses}

- The plant is used as antiseptic.

- The leaves, stems and seeds contain alkaloid.

- The paste of root with decoction of stem bark of Terminalia arjuna (3:2) used to treat cholera ${ }^{11}$.
- The plant Croton bonplandianum (Euphorbiaceae) is treat liver disorders, skin diseases including ring worm infection, to cure the swelling of body, bronchitis and asthma.

\section{JATROPHA GOSSYPIFOLIA L.}

- Botanical Name : J. gossypifolia L

- Binomial Name : Jatropha gossypifolia L

- Local Name : Lal bherenda.

- Family: Euphorbiaceae.

Habit: Shrub.

Habitat: Open sunny places.

Flower colour: Reddish-purple.

Flowering season: April-August.

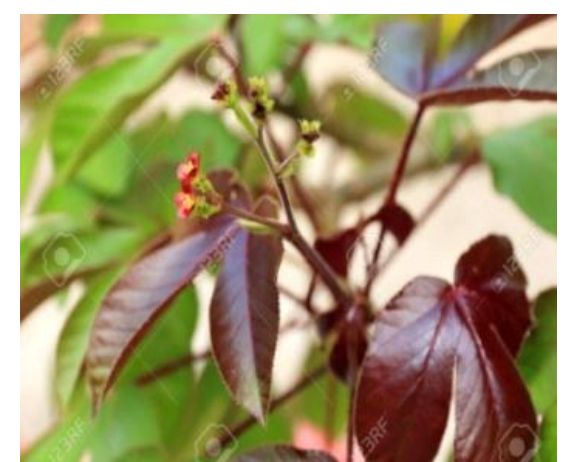

Figure 5: Jatropha gossypifolia L.

\section{Parts utilized}

Leaves, flowers and root

Medicinal uses

- The leaves are used on boils and carbuncles, eczema and itches ${ }^{12}$

- The Seeds cause insanity and act as an emetic.

- It is also grown as an ornamental plant. The leaves and the seeds are used as purgative.

- The stem-juice in nostrils to cure headache

- The leaves and bark have the same purgative effect.

- The oil is applied to treat rheumatic conditions and a variety of skin infections, although its use on the skin may also cause an irritative rash.

- The sap has a widespread reputation for healing wounds, as a haemostatic and for curing

- Skin problems; it is applied externally to treat infected wounds, ulcers, cuts, abrasions, ringworm, eczema, dermatomycosis, scabies and venereal diseases.

\section{RICINUS COMMUNIS L.}

- Botanical Name : R. comanis L.

- Binomial Name: Ricinus communis $L$.

- Local Name : Bherenda.

- Family: Euphorbiaceae.

Habit: Small tree.

Habitat: Dry and sandy expose areas.

Flower color: Red.

Flowering season: April-September.

Parts Utilized: Whole plants, leaves, flowers, fruits and seeds.

Medicinal uses 
- Seed oil is a strong purgative; used externally as a and internally for the treatment of constipation ${ }^{13}$. massage for rheumatic pains, joint pain, paralysis

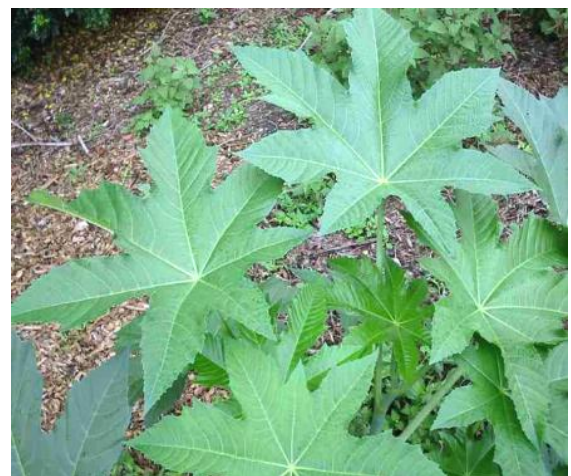

Figure 6: Ricinus communis $L$.

Table 1: Plants chemical components and activities

\begin{tabular}{|c|c|c|}
\hline Plants Name & $\begin{array}{l}\text { Parts } \\
\text { Used }\end{array}$ & Chemical components \\
\hline Acalyphaindica $\mathbf{L}$ & $\begin{array}{l}\text { Leaves, } \\
\text { stem, } \\
\text { flowers, } \\
\text { roots and } \\
\text { seeds. }\end{array}$ & $\begin{array}{l}\text { Alkaloids, catachols, phenolic compounds, } \\
\text { flavinoids, saponin, steroids and tannin. }\end{array}$ \\
\hline $\begin{array}{l}\text { Euphorbia hirta } \\
\boldsymbol{L}\end{array}$ & $\begin{array}{l}\text { Leaves, } \\
\text { stem and } \\
\text { roots and } \\
\text { flower. }\end{array}$ & $\begin{array}{l}\text { Quercitrin, myricitrin, } \\
\text { leucocyanidin, quercetin, } \\
\text { kaempferol, maleic acid, tartaric acid, rutin, } \\
\alpha \text {-amyrin. }\end{array}$ \\
\hline
\end{tabular}

\begin{tabular}{|c|c|c|c|}
\hline $\begin{array}{l}\text { Euphorbia } \\
\text { thymifolia } \mathbf{L}\end{array}$ & $\begin{array}{l}\text { Leaves, } \\
\text { roots, } \\
\text { flowers } \\
\text { and whole } \\
\text { plant. }\end{array}$ & $\begin{array}{l}\text { Quercetin galactoside, } \quad \beta \text {-amyrin, } \beta- \\
\text { sitosterol, cholesterol, kaempferol, salicylic } \\
\text { acidesters, n-alkanes, sterol, glycoside, } \\
\text { Taraxerol, sterols , Crudeprotein, } \\
\text { fatandfiber, total carbohydrate, starch, } \\
\text { amylase, amylopectin, cellulose, acid } \\
\text { insoluble and soluble ash, Macro-minerals } \\
\text { viz, Na, K, Ca, Li and micro-minerals viz, } \\
\mathrm{Fe}, \mathrm{Cu}, \mathrm{Mn} \text { and Co. }\end{array}$ & $\begin{array}{l}\text { Anti-inflammatory and proven to encourage } \\
\text { healthy cell growth and function, analgesic, } \\
\text { haemostatic, anti-thrombic, antioxidant, } \\
\text { vasoprotective actions, antiviral, anti-allergic, anti- } \\
\text { tumour properties, antioxidant, anti-helminthic, } \\
\text { antibacterial activities, antidiabetic, anti } \\
\text { hyperlipidemic activity, antibacterial, antifungal, } \\
\text { antimicrobial, anti-anxiety activity, anti-nociceptive } \\
\text { activities. }\end{array}$ \\
\hline $\begin{array}{l}\text { Croton } \\
\text { bonplandia-num } \\
\text { baill }\end{array}$ & $\begin{array}{l}\text { Leaves, } \\
\text { fruits and } \\
\text { flowers. }\end{array}$ & $\begin{array}{l}\text { 1-Dodecene, 1-Dodecanol, 1-Tetradecene, } \\
\text { 2, 4-bis (1, 1 dimethylethyl)-phenol Methyl } \\
\text { stearate, n-Tetracosanol-1, triterpene e.g. } \\
\text { squalene(2,6,10,15,19,23hexamethyltetraco } \\
\text { sa 2,6,10,14,18,22-hexaene),linoleate } \\
\text { e.g.octadeca-9,12-dienoic acidoxo (keto), } \\
\text { fatty acid esters e.g. methyl } 12 \text { oxooctadec- } \\
\text { 9-enoate, cardenolides, diterpene e.g. } \\
\text { phytol, alkaloids, terpenoids, flavonoids, } \\
\text { tannins,steroids. }\end{array}$ & $\begin{array}{l}\text { Wound healing activity, anti-tuberculosis activity, } \\
\text { anti-fungal activity, antioxidant, anti-inflammatory } \\
\text { activity, antibacterial, anti-tubercular, cytotoxic } \\
\text { activities, cancer preventive, immune stimulant, } \\
\text { chemo preventive, lipoxygenase-inhibitor, } \\
\text { pesticide, hypocholesterolemic, nematicide, anti- } \\
\text { arthritic, hepatoprotective, anti androgenic, } \\
\text { hypocholesterolemic 5-alpha reductase inhibitor, } \\
\text { antihistaminic, anti coronary, insectifuge, anti- } \\
\text { eczemic, anti-acne }{ }^{10} \text {. }\end{array}$ \\
\hline
\end{tabular}

\begin{tabular}{|c|c|c|c|}
\hline $\begin{array}{l}\text { Jatropha } \\
\text { gossypifolia L }\end{array}$ & $\begin{array}{l}\text { Leaves, } \\
\text { flowers } \\
\text { and root. }\end{array}$ & $\begin{array}{l}\text { Coumarin, lignoids, diterpenes, flavonoids, } \\
\text { fatty acid, lignans, saponin, phenol, } \\
\text { glycoside, esters. }\end{array}$ & $\begin{array}{l}\text { Anti-inflammatory activity, antimicrobial activity, } \\
\text { antibacterial activities, anti-diarrhoeal activity, anti- } \\
\text { fungal activity, phytochemical activity, allelopathic } \\
\text { activity, antioxidant activity, analgesic activity. }\end{array}$ \\
\hline $\begin{array}{l}\text { Ricinus } \\
\text { communis L }\end{array}$ & $\begin{array}{l}\text { Wholeplan } \\
\text { ts,leaves,fl } \\
\text { owers,fruit } \\
\text { s and } \\
\text { seeds. }\end{array}$ & $\begin{array}{l}\text { Palmitic, Stearic, Oleic } \mathrm{C}_{18: \ln 9,} \\
\text { Oleic } \mathrm{C}_{18: \ln 10,} \\
\text { Linoleic,Ricinoleic,Dihydroxy stearic } \\
\text { acid,Unsaturated fatty acid (UFA), } \\
\text { Saturated fatty acid (SFA). }\end{array}$ & $\begin{array}{l}\text { Mutagenicity, cytotoxic and antioxidant activities, } \\
\text { anti fertility, antibacterial activity, antimicrobial } \\
\text { activity, analgesic activity, catalytic activity, } \\
\text { larvicidal activity, insecticidal activities, antifungal } \\
\text { activities }{ }^{11} \text {. }\end{array}$ \\
\hline
\end{tabular}




\section{CONCLUSION}

The review given here is to be used for identification of the medicinal and economical plants commercially. Active principles isolated from different plants can be utilized as leads for further drug development by the pharmaceutical industry. This study provides important data for identification of different plants in Euphorbiaceae family. This review will be benificial for many researchers for their work on plants of Euphorbiaceae family.

\section{AUTHOR'S CONTRIBUTION}

All authors have worked equally for this work.

\section{ACKNOWLEDGEMENTS}

The authors extend their thanks and appreciation to the University of Science and Technology Chittagong (USTC), Bangladesh to provide necessary facilities for this work.

\section{CONFLICT OF INTEREST}

Authors have declared that no conflict of interest is linked with this work.

\section{REFERENCES}

1. Betancur-Galvis LA, Morales GE, Forero JE, Roldan J. Cytotoxic and antiviral activities of colombian medicinal plant extracts of the euphorbia genus. Memórias do Instituto Oswaldo Cruz 2002; 97(4): 541-546. https://doi.org/10.1590/S0074-02762002000400017

2. Gillespie L J, Armbruster,WS. A Contribution to the Guianan Flora: Dalechampia, Haematostemon, Omphalea, Pera, Plukenetia, and Tragia (Euphorbiaceae) with Notes on Subfamily Acalyphoideae. Smithsonian Contributions to Botany 1997; (86): 6.https://doi.org/10.5962/bhl.title.103726

3. Davidson-HuntI2000: Ecologica ethn botany: Stumbling toward new practices and paradigms. MASAJ, 16: C13, 2000 .
4. UNESCO. Culture and Health, Orientation Texts-World Decade for Cultural Development 1988-1997, Document CLT/DEC/PRO-1996, Paris, France, 1996, 129. https://doi.org/10.11648/j.jps.s.2015030101.18

5. Abdel-Wahab SI, A in NM, Abdul BA, Elhassan MM, Ibrahim TAT. Energy-Dispersive X-Ray micro analysis of elements? Content of medicinal plants used traditionally as anticancer cure. Res J Biol Sci 2009; 4(5):547-549.

6. Bernhoft A. A brief review on bioactive compounds in plants, In: Bioactive compounds in plants-benefits and risks for man and animals, Oslo: The Norwegian Academy of Science and Letters, 2010, 11-17.

7. Kumar S, Malhotra R, Kumar D. Euphorbia hirta: Its chemistry, traditional and medicinal uses, and pharmacological activities. Pharmacognosy Reviews 2010; 4 (7): 58-61. https://doi.org/10.4103/0973-7847.65327

8. Kwan YP, Saito T, Ibrahim D, Al-Hassan FM, Ein Oon C, Chen $\mathrm{Y}$, et al. Evaluation of cytotoxicity, cell-cycle arrest and apoptotic induction by Euphorbia hirta in MCF-7 breast cancer cells. J Ethnopharmacol. 2015; 165:180-90. https://doi.org/10.3109/13880209.2015.1064451

9. Singh R. Medicinal Plants: A Review. J Plant Sci. Med Plants 2015; 3(1):50-55.doi:10.11648/j.jps.s.2015030101.18. https://doi.org/10.11648/j.jps.s.2015030101.18

10. Jones WP, Chin YW, Kinghorn AD. The role of pharmacognosy in modern medicine and pharmacy. Curr Drug Targets 2006; 7:247-264. https://doi.org/10.2174/138945006776054915

11. Chen J, Er HM. Mohamed SM, Chen YS. In vitro antiinflammatory activity of fractionated Euphorbia hirta aqueous extract on rabbit synovial fibroblasts. Pharmacognosy Res 2015; 1:7-13.

12. Kumar N, Wani ZA, Dhyani S. Ethnobotanical study of the plants used by the local people of Gulmarg and its allied areas, Jammu and Kashmir, India. Int J Curr Res Biosci Plant Biol 2015; 2(9):16-23.

13. Bassam Abdul RH. Medicinal Plants (Importance and Uses). Clinical Pharmacy Discipline, School of Pharmaceutical Sciences, University of Sains Malaysia, 11800, Penang, Malaysia. Pharmaceutica Analytica Acta 2012; 3: e139. https://doi.org/10.4172/2153-2435.1000e139 